\title{
Identification of vulture species around galagu station in Dinder national park, February 2017
}

\begin{abstract}
This study was conducted in Dinder National Park, which consists of many types of trees and also many wildlife species. The purpose of this research was to identify the vulture species, their population sizes and distribution in the park. The out bound approach method was used to determine their population sizes and chi square test to determine their habitat use and preferences. Five species of vultures were identified in Dinder National Park including, Hooded Vulture (Necrosyrtes monachus), Whitebacked Vulture (Gypes africanus), White-headed Vulture (Trigonoceps occipitalis), Ruppell Vulture (Gypes rueppillii) and Egyptian Vulture (Neophron perconopterus). We estimated the population of Hooded Vulture to be $888 \leq 114$, white-headed Vulture at $256 \leq 40$, Egyptian Vulture at $41 \leq 5$, Ruppell Vulture at $41 \leq 5$ and white headed vulture to be $40 \leq 4$ around Galagu in the park. Chi square test showed no significant different between habitats use by the four vulture species suggesting that vultures were found in the three types of habitat found in the park, while White-backed Vulture (Gypes africanus) showed highly preference for un burned woodland habitat.
\end{abstract}

Volume I Issue 6 - 2017

Tahani Ali Hassan, Omar Abdullah Ismail

Department of Wildlife, University of Bahri, Sudan

\author{
Correspondence: Tahani Ali Hassan, Department of Wildlife, \\ College of Natural Resources and Environmental Studies, \\ University of Bahri, Khartoum North, Sudan, \\ Email tahanihassanm@gmail.com
}

Received: November 14, 2017 | Published: December 28 2017

Keywords: vultures, dinder national park, habitat preferences

\section{Introduction}

Vulture is the name given to two groups of scavenging birds of prey: the new world vulture including the California and Andean condors and the old world vulture, including the birds that are seen scavenging on animal carcasses on African plains. New world vultures are found in North and South America and old world vultures are found in Europe, Africa, and Asia; between the two groups, vultures are found on every continent except Australia and Antarctica. Vultures are uniquely equipped to keep the Environment clean and help prevent the spread of disease. Most vultures eat carrion which includes dead animals in all stages of decomposition. Though they prefer mammalian carrion, vultures also eat reptiles, amphibian, fish and bird carcasses.

As with all wildlife, loss of habitat is the most significant problem facing vulture ${ }^{1}$ While vultures are able to migrate and some can adapt to urban environments, the continued loss of habitat to human use is putting pressure on many species. Other threat comes indirectly from poison based pest control efforts. Poisoned carcasses of rats, mice and insects, coyotes, can be ingested, which can kill vultures (Sinclair 1986). Birds of prey in South Africa, however, are most threatened by the loss of habitat caused by the spread of the human activity. Habitat loss reduces breeding site availability and hinders foraging (Sinclair 1986). While in Dinder National Park no studies have been conducted on vultures so far, but a study of Raptors of Dinder National ${ }^{2}$ listed four species of vulture as present. No in depth studies have been carried on habitat range and distribution and no proper population census have been conducted on vulture in Sudan's National Parks and in particular Dinder National Park. The objective of this study was to identify the vulture species and their population sizes and distribution in Dinder National Park and habitat use and preference by vulture species in Dinder National Park.

\section{Study area}

This study was conducted in Dinder National Park $\left(11^{\circ} 45\right.$ E $12^{\circ}$
$50 \mathrm{~N}, 34^{\circ} 30 \mathrm{E} 36^{\circ} 00 \mathrm{~N}$ ). Established in 1935, the park which is 650,000 ha lies and located at the south eastern part of Sudan against the Ethiopian frontier (Figure 1). The area of the park principally consists of a low-lying flood plain that slopes gently from the Ethiopian highlands with few rocky hills at its southern corner. ${ }^{4}$ The Rahad and Dinder rivers flow north-westerly through the park area. Tributary streams form seasonally flooded lowlands, known as Mayas (marches) in much of the area adjacent to the Ethiopian border. The park comprises three ecosystems: Maya, Riverine and Dahara. ${ }^{5}$ Vegetation in these ecosystems is described as consisting of grasslands, wooded land and riparian forest.

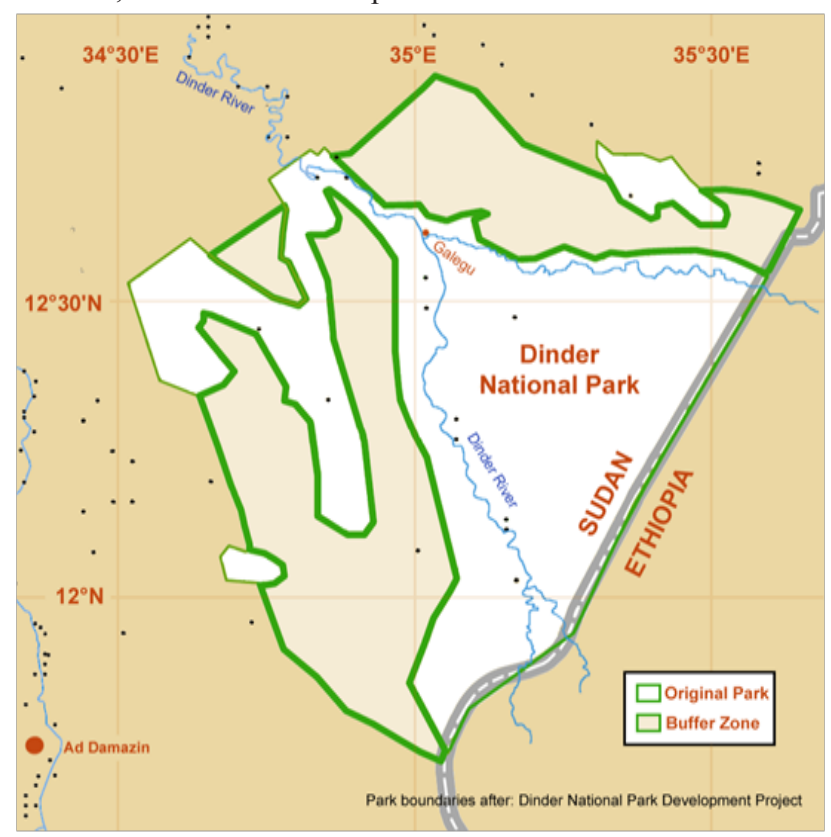

Figure I The Dinder National Park (Source: https://www.britannica.com/ place/Dinder-National-Park appeared on 4/22/20I7). 
Along seasonal streams, the vegetation consists of Hyphaene thebaica, Acacia sieberiana, Tamarindus indica and Ficus spp.; the understory vegetation is primarily comprised of Ziziphus spina Christi and Mimosa pigra. Coarse grasses, including Sorghum PP. and Brachiaria spp. dominate the herbaceous layer. Thorn-bush savanna (Acacia seyal-Balanites aegyptica association) with tall grasses dominates the north, while Combretum aculeatum woodland is found in the moister south. Nymphaeaceae and Ipomoea spp. are common in Mayas and shallow lakes, while the open grass plains are covered by Themeda triandra, Panicum, Hyparrhenia and Cynodon spp. The Mayas, the main source of water and green fodder during the dry season (November-June), are dominated by Echinochloa spp.

Dinder National Park has a mean annual rainfall of 600-1,000 mm, falling between May and November. Ten villages currently fall inside the park and there are 38 villages less than one kilometer from the external boundary of the park. ${ }^{3}$

\section{Materials and methods}

\section{Data collection}

The survey covered the entire study area but the intensive study was confined in woodland around the Galagu area and Mayas (marsh) such as Gererisa, Abdulghani, Ras Amir, Einelshames, Mussa and Faresh elnaam.

\section{Method}

The method used in this survey was out-bound approach method the survey was carried out in Dinder National Park in the dry season between February and April 2017. The count covered the woodland around Galagu and the Mayas all were selected at random, the counting was during the morning and evening hours. The number of the vulture species seen were identified and recorded.

\section{Materials}

Each observer was provided with a data sheet and pen to record the number of all birds seen and their frequency while walking on foot. A field guide of birds was also used for identification of birds during the counting, a pair of binoculars was used effectively to identify the species of vulture those far away. Several counts were conducted for each habitat to ensure good coverage of the area.

\section{Data analysis}

The out-bound approach (Robson and Whitlock 1954) is based on a rationale that an observer will see more animal on some days than on others and that the highest count can be used to probability theory. The outer-bound method of population estimate observed makes counts repeatedly eventual then will appear the highest value and the next highest value the $\mathrm{N}$, the population estimate.

$$
\mathrm{N}=2 \mathrm{n}_{\mathrm{k}}-\mathrm{n}_{\mathrm{k}-1}
$$

Where:

$\mathrm{N}$ : The number of population estimate from the counts.

$\mathrm{n}_{\mathrm{k}}$ : The largest number of animals observed.

$\mathrm{n}_{\mathrm{k}-1}$ : Is the second largest number of animals observed.

2: Correction factor
The upper confidence limit is calculated as follows

$$
N H=\frac{n k(1+a)}{a}\left(n_{k}-n_{k-1}\right)
$$

Where

$\mathrm{NH}$ : The upper confidence limit of the population

A: Confidence limit (0.05)

$\mathrm{N}$ : Is also considered a lower confidence limit.

There for the population estimate $(\mathrm{N})$ is given by:

Lower limit $<\mathrm{N}<$ upper limit.

A chi-square test of independence was done to compare habitat use by species.

$x^{2}=\frac{(O-E)}{E}$

O: Observed value from the habitat used burnt and un brunt.

E: Expected value from habitat used burnt and un burnt.

\section{Results and discussion}

\section{Results}

A total of five vulture species and 201 individuals were identified during visual surveys in Dinder National Park from February - April 2017 (see Table 1 for break down by species).The population estimate of Hooded Vulture is $888 \leq 114$, white-headed Vulture is $256 \leq 40$, Egyptian Vulture is $41 \leq 5$, Ruppell Vulture is $41 \leq 5$ and white headed vulture is $40 \leq 4$ around Galagu in the park. The chi-squire test showed no significant differences in habitat use by the Hooded Vulture $\left(\chi^{2}=1.8^{\mathrm{ns}}, \mathrm{df}=3, \mathrm{P}=0.05\right)$ while White-backed Vultures showed highly significant difference in habitat uses $\left(\chi^{2}=8.95^{* *}, \mathrm{df}=3, \mathrm{P}=0.05\right)$. We detected too few (insufficient sample sizes) Egyptian Vultures, Ruppell Vultures and White-headed vultures to run chi-square tests on habitat use.

\section{Discussion}

Five species of vultures were identified in Dinder National Park including, Hooded Vulture (Necrosyrtes monachus), White-backed Vulture (Gypes africanus), White-headed Vulture (Trigonoceps occipitalis), Ruppell Vulture (Gypes rueppillii) and Egyptian Vulture (Neophron perconopterus). In general, the population size of any species in a given area is determined by factors such as natural habitat variation and manmade structures. In Dinder National Park the population sizes of vultures' species varies greatly. This variation could be due to the fact that each species has unique environmental requirements such as food, water, cover and climate. Overall all but white backed vulture showed strong preference for woodland habitat.

Hooded Vultures were counted in greater numbers than other vulture species observed. Hooded Vultures appeared well distributed across habitats in Dinder National park (Table 1). The number of Hooded Vulture and white-backed Vulture is greater in woodland habitat. Hooded Vultures primarily feed on carrion, insects and bones, ${ }^{5}$ which may occur in greater abundance in woodland habitat. White-backed vulture feeds on carrion which is available in woodland habitats and also their nesting places are very safe this in line with findings of Lwanga ${ }^{2}$ (Table 2) (Table 3 ). Vultures species were equally 
distributed across the three different habitats measured within Dinder National Park. This means that each species of Vulture has no specific habitat that is to say they move all around the habitats and found their basic requirement such as water, food and cover in every habitats in
Dinder National Park. Although no differences in habitat use were detected by species, Egpytian, White-headed, and Ruppell Vultures did not have sufficient samples sizes to compare relative habitat use (Tables 4-6).

Table I The Number of Vulture species counted in the four directions around Galagu station in Dinder National Park during the dry season 2017

\begin{tabular}{llllll}
\hline Direction & Eastern & Western & Northern & Southern & Total \\
\cline { 1 - 4 } Vulture Species & & & & & \\
\hline Hooded Vulture (Necrosyrtes monachus) & 71 & 15 & 28 & 26 & 140 \\
White-backed Vulture (Gypes africanus) & 16 & 2 & 28 & 5 & 51 \\
White-headed Vulture & 0 & 0 & 0 & 2 & 2 \\
$\begin{array}{l}\text { (Trigonoceps occipitalis) } \\
\text { Egyptian Vulture (Neophron perconopterus) }\end{array}$ & 3 & 0 & 0 & 1 & 4 \\
Ruppell Vulture (Gypes rueppillii) & 3 & 0 & 1 & 0 & 4 \\
Total & & & & 201 \\
\hline
\end{tabular}

Table 2 Habitat type and condition preferences by Hooded Vulture (Necrosyrtes monachus) around Galagu station in Dinder National Park during the dry season 2017

\begin{tabular}{lllllll}
\hline Direction & Habitat type & & \multicolumn{2}{c}{ Habitat condition } & \multirow{2}{*}{ Total ground } \\
\cline { 2 - 5 } & Woodland & Riverine & Grassland & Burned & Unburned & \\
\hline Eastern & 40 & 20 & II & 26 & 45 & 71 \\
Western & 10 & 5 & 0 & 5 & 10 & 15 \\
Northern & 15 & 8 & 5 & 10 & 18 & 28 \\
Southern & 15 & 6 & 5 & 13 & 13 & 26 \\
Total & & & & $\mathbf{5 4}$ & $\mathbf{8 6}$ & $\mathbf{1 4 0}$ \\
\hline
\end{tabular}

Table 3 Habitat type and condition preference by White-backed Vulture (Gypes africanus) around Galagu station in Dinder National Park during the dry season 2017

\begin{tabular}{lllllll}
\hline Direction & Habitat type & & \multicolumn{2}{c}{ Habitat condition } & Total ground \\
\cline { 2 - 6 } & Woodland & Riverine & Grassland & Burned & Unburned & \\
\hline Eastern & 10 & 4 & 2 & 6 & 10 & 16 \\
Western & 2 & 0 & 0 & 0 & 2 & 2 \\
Northern & 10 & 10 & 8 & 10 & 18 & 28 \\
Southern & 5 & 0 & 0 & 5 & 0 & 5 \\
Total & & & & $\mathbf{2 1}$ & $\mathbf{3 0}$ & $\mathbf{5 1}$ \\
\hline
\end{tabular}

Table 4 Habitat type and condition preference by Egyptian Vulture (Neophron perconopterus) around Galagu station in Dinder National Park during the dry season 2017

\begin{tabular}{lllllll}
\hline \multirow{2}{*}{ Direction } & Habitat type & & & \multicolumn{2}{l}{ Habitat condition } & \multirow{2}{*}{ Total ground } \\
\cline { 2 - 5 } & Woodland & Riverine & Grassland & Burned & Unburned & \\
\hline Eastern & 3 & I & 0 & 2 & I & 3 \\
Western & 0 & 0 & 0 & 0 & 0 & 0 \\
Northern & 0 & 0 & 0 & 0 & 0 & 0 \\
Southern & 0 & 0 & 0 & I & 0 & I \\
Total & & & & $\mathbf{3}$ & $\mathbf{1}$ & $\mathbf{4}$ \\
\hline
\end{tabular}


Table 5 Habitat type and condition preference by Ruppell Vulture around Galagu station in Dinder National Park during the dry season 2017

\begin{tabular}{lllllll}
\hline \multirow{2}{*}{ Direction } & Habitat type & & \multicolumn{2}{c}{ Habitat condition } & \multirow{2}{*}{ Total ground } \\
\cline { 2 - 5 } & Woodland & Riverine & Grassland & Burned & Unburned & \\
\hline Eastern & 3 & 0 & I & 2 & I & 3 \\
Western & 0 & 0 & 0 & 0 & 0 & 0 \\
Northern & 0 & 0 & 0 & 0 & I & I \\
Southern & 0 & 0 & 0 & 0 & 0 & 0 \\
Total & & & & $\mathbf{2}$ & $\mathbf{2}$ & $\mathbf{4}$ \\
\hline
\end{tabular}

Table 6 Habitat type and condition preference by White-head Vulture around Galagu station in Dinder National Park during the dry season 2017

\begin{tabular}{lllllll}
\hline \multirow{2}{*}{ Direction } & Habitat type & & & \multicolumn{2}{l}{ Habitat condition } & \multirow{2}{*}{ Total ground } \\
\cline { 2 - 5 } & Woodland & Riverine & Grassland & Burned & Unburned & \\
\hline Eastern & 0 & 0 & 0 & 0 & 0 & 0 \\
Western & 0 & 0 & 0 & 0 & 0 & 0 \\
Northern & 0 & 0 & 0 & 0 & 0 & 0 \\
Southern & 0 & 2 & 0 & 0 & 2 & 2 \\
Total & & & & $\mathbf{0}$ & $\mathbf{2}$ & $\mathbf{2}$ \\
\hline
\end{tabular}

\section{Conclusion}

The out bound approach method was adapted to determine the number and distribution of Vultures species around Galagu in Dinder National Park in three habitats Woodland, Riverine and Maya ecosystem. The vulture species showed preference of woodland habitats which demands for more effort to protect them and their preferred habitats.

\section{Recommendation}

a. Preservation of natural habitats from degradation and destruction through cutting of trees and controlled burning.

b. Since no studies on Vulture species in Dinder National Park, Sudan, further studies are needed to identify vulture species and their habitat preferences in the park.

\section{Acknowledgments}

My thanks are due to the university of Bahri Administration for providing the logistics and financial assistance and students of the department of wildlife sciences for their collaboration in the field, last we thanks the wildlife general administration for assistance they provided to work in the field.

\section{Conflict of interest}

Author declares there is no conflict of interest in publishing the article.

\section{References}

1. Richard M. The atlas of endangered species. University of California press, USA; 2009.

2. Lwanga TC. Estimating population of Raptors in Dinder National Park. Khartoum, Sudan; 2007.

3. Anonymous. Dinder National Park Management Plan study. Higher Council for Environment and Natural Resources, Wildlife Conservation General Administration. Sudan; 2003. p. 51-54.

4. Hakim S, Fadlalla B, Awad NM, et al. Ecosystems of the vegetation of Dinder National Park. Unpublished report, Wildlife Research Center, Khartoum, Sudan; 1979.

5. Brown NH, Amadon D. Eagles, Hawks, and Falcons of the world. Country life, Feltham, UK; 1968.

6. Sinclaire I, Ryan P. Birds of south of the Sahara. Struck, Cap town, South Africa; 2003. 